\title{
Prediction Of Drug Sales Using Methods Forecasting Double Exponential Smoothing (Case Study : Hospital Pharmacy of Condong Catur)
}

Prediksi Penjualan Obat dengan Menggunakan Metode Peramalan Double Exponential Smoothing (Studi Kasus : Apotek Rumah Sakit Condong Catur)

\section{Annesa Maya Sabarina ${ }^{1}$, Heru Cahya Rustamaji², Hidayatulah Himawan ${ }^{3}$}

1,2,3 Informatika, Universitas Pembangunan Nasional Veteran Yogyakarta, Indonesia

19annesa.ms98@gmail.com, ${ }^{2 *}$ herucr@gmail.com, ${ }^{3}$ if.iwan@gmail.com

*: Penulis korenspondensi (corresponding author)

\section{Informasi Artikel}

Received: 12 December 2020

Revised: 12 January 2021

Accepted: 30 January 2021

Published: 28 February 2021

Keywords: Sales; Prediction; Pharmacies; Double Expoenential Smoothing; Alpha

Kata kunci: Penjualan; Prediksi; Apotek; Double Expoenential Smoothing; Alpha

\begin{abstract}
Purpose: Knowing the best alpha value from the data for each type of drug with various alpha parameters in the Double Exponential Smoothing Method and knowing the prediction results on each type of drug data at the Condong Catur Hospital pharmacy.

Design/methodology/approach: Applying the Double Exponential Smoothing method with alpha parameters 0.1; $0.2 ; 0.3 ; 0.4 ; 0.5 ; 0.6 ; 0.7 ; 0.8 ; 0.9$

Findings/result: The test results on a system built using test data show that the double exponential smoothing method provides accuracy below $20 \%$ by producing a different Alpha ( $\alpha$ ) for each type of drug because the trend patterns in each drug sale are different at the Pharmacy at the Condong Catur Hospital. .

Originality/value/state of the art: Based on previous research, this study has similar characteristics such as themes, parameters and methods used. Previous researchers used smoothing methods such as Double Exponential Smoothing in predicting stock / sales of goods
\end{abstract}

Abstrak
Tujuan: Mengetahui nilai alpha terbaik dari data tiap jenis
obat dengan berbagai macam parameter alpha pada Metode
Double Exponential Smoothing serta mengetahui hasil
prediksi pada setiap jenis data obat pada apotek RS
Condong Catur.
Perancangan/metode/pendekatan: Menerapkan metode
Double Exponential Smoothing dengan parameter alpha
0,$1 ; 0,2 ; 0,3 ; 0,4 ; 0,5 ; 0,6 ; 0,7 ; 0,8 ; 0,9$.


Hasil: Hasil pengujian pada sistem yang dibangun mengunakan data uji memperlihatkan bahwa metode double exponential smoothing memberikan akurasi dibawah $20 \%$ dengan menghasilkan Alpha $(\alpha)$ yang berbeda-beda pada setiap jenis obat karena pola trend pada setiap penjualan obat berbeda-beda di Apotek Rumah Sakit Condong Catur.

Keaslian/ state of the art: Berdasarkan penelitian terdahulu, penelitian ini memiliki karakteristik yang serupa seperti tema, parameter dan metode yang digunakan. Peneliti terdahulu menggunakan metode smoothing seperti Double Exponential Smoothing dalam melakukan prediksi stok/penjualan barang.

\section{Pendahuluan}

Dalam era globalisasi saat ini, organisasi dan perusahaan membutuhkan suatu sistem informasi untuk mendukung aktivitasnya [1]. Pengadaan adalah segala kegiatan dan upaya untuk meningkatkan dan memenuhi permintaan barang dan jasa sesuai dengan ketentuan yang berlaku atau dengan menciptakan barang yang sebelumnya tidak ada. Ini termasuk upaya untuk mempertahankan yang sudah ada dalam batas efisiensi.

Salah satu cara untuk meningkatkan efektivitas pengadaan adalah melakukan permalan pada prediksi penjualan obat. Peramalan (forecasting) merupakan suatu proses atau usaha untuk mengetahui peristiwa-peristiwa (event) yang akan terjadi dimasa mendatang dengan menggunakan data histori atau masa lalu berdasarkan objek, pengalaman-pengalaman, ataupun data tertentu. Deret berkala (time series) merupakan model yang memprediksi masa depan dengan menggunakan data masa lalu yang berurutan dengan beberapa periode waktu tertentu. Model deret berkala (time series) memiliki 3 teknik permalan yaitu metode penghalusan (smoothing methods), metode dekomposisi dan metode Box-Jenkis [2]. Metode penghalusan (smoothing methods) terdiri dari metode rata-rata (average methods) dan penghalusan eksponensial (exponential smoothing methods). Untuk mengetahui metode permalan yang baik pada time series dapat diketahui dengan melihat pola data pada histori masa lalu. Pola data dapat dibagi menjadi empat yaitu pola data trend, musiman, horizontal atau siklis.

Metode double exponential smoothing merupakan salah satu metode peramalan penghalusan eksponensial (exponential smoothing methods) yang datanya berpola trend dan tidak musiman. Parameter yang digunakan untuk menghaluskan data yaitu $\alpha$ (alpha) dengan nilai $0<\alpha<1$ [3]. Menurut [4] metode double exponential smoothing adalah metode yang baik digunakan untuk memprediksi data yang mengalami tren naik maupun turun.

Pada penelitian sebelumnya yang berkaitan dengan penjualan produk farmasi di apotek dengan menggunakan metode single exponential smoothing dan brown exponential smoothing yang dilakukan oleh [5] dengan parameter $\alpha=0,1 ; \alpha=0,3 ; \alpha=0,5$ dan $\alpha=0,7$ untuk pembelian produk farmasi. Pada penelitian ini, setiap jenis obat diproses dengan beraneka alpha, lalu nilai MAPE paling minimum dikelompokkan dan diambil rata-rata alpha yang tinggi. Hasil dari 
penelitian tersebut menunjukkan bahwa metode single exponential smoothing didapatkan nilai rata-rata $\alpha=0,5$ dengan nilai persentase MAPE yaitu 1,14\% lebih baik dibandingkan dengan metode brown exponential smoothing dengan nilai persentase MAPE yaitu 1,22\% dengan $\alpha=$ 0,1 . Namun, pada penelitian ini apabila mengambil nilai rata-rata alpha tidak semua produk farmasi menghasilkan nilai error paling kecil.

Pada penelitian [6] dalam melakukan prediksi kebutuhan obat dengan menggunakan metode double exponential smoothing dan paramaeter alpha yang digunakan yaitu 0,1-0,9. Dari hasil pengujian tersebut didapatkan nilai rata-rata alpha terdapat pada alpha 0,5 dengan nilai minimum MAPE dibawah 20\%, sehingga alpha yang dipakai untuk prediksi kebutuhan obat adalah 0,5. Namun, tidak semua alpha 0,5 menghasilkan nilai error minimum dalam melakukan peramalan untuk semua jenis obat. Dapat dilihat dari penelitian [7] yang menggunakan metode triple exponential smoothing untuk menganalisis permalan persediaan obat digunakan dua jenis data yaitu data trend liner dan data fluktuatif. Hasil dari metode triple exponential smoothing dengan parameter $\alpha=0,1$ untuk data liner menghasilkan nilai error terkecil yaitu 28,3415,8\%, sedangkan untuk data fluktuatif menghasilkan nilai MAPE terkecil 4,25448\%. Dapat diketahui metode triple exponential smoothing memiliki kekurangan dalam menghitung data yang berjenis trend liner.

Kendala dalam perencanaan pengadaan obat yaitu pemakaian obat yang tidak beraturan. Kendala ini mempersulit departemen pengadaan obat dalam memprediksi kebutuhan pemakaian obat untuk satu bulan berikutnya. Kesalahan perencanaan pengadaan obat dapat mengakibatkan terjadinya kelebihan atau kekurangan persediaan obat [8]. Pengadaan yang tidak terawasi dan terlalu sedikit dapat menyebabkan terjadinya stock out pada persediaan obat di apotek sehingga tidak dapat memenuhi permintaan konsumen. Selain itu, stock out juga dapat menyebabkan back order, yang merupakan pesanan dari pembeli yang tidak dapat dipenuhi penjual pada waktu yang diminta oleh pembeli (Yunarto, 2005). Sedangkan apabila kelebihan persediaan obat dapat mengakibatkan fasilitas penyimpanan menjadi overload dan rumah sakit harus mengeluarkan biaya tambahan untuk menjaga penyimpanan dan pemeliharaan obat guna menjaga kualtias obat. Selain itu obat memiliki batas waktu kadaluarsa, apabila obat disimpan terlalu lama maka dapat menyebabkan terjadinya kadaluarsa, waste (pemborosan) pada obat dan kerugian pada rumah sakit [9].

Pada pengadaan obat di apotek RS Condong Catur, apoteker yang bertugas selalu membuat laporan berapa jumlah obat yang terjual setiap malam. Apabila terdapat obat yang menipis atau stok kosong, paginya apoteker yang bertugas menginfokan ke gudang untuk melakukan pemesanan. Perencanaan yang tidak tepat dapat menyebabkan terjadinya overstock atau stock out pada stok obat. Berdasarkan uraian diatas, maka akan dilakukan penelitian tentang prediksi penjualan obat dengan menggunakan metode peramalan double exponential smoothing guna mendapat informasi penjualan obat dimasa yang akan datang. Selanjutnya akan dianalisa apakah metode peramalan double exponential smoothing efektif digunakan untuk prediksi penjualan obat dengan menggunakan parameter alpha. Alpha (a) merupakan parameter yang digunakan pada metode double exponential smoothing untuk melakukan penghalusan peramalan, dimana nilai parameter alpha berpengaruh untuk menentukan hasil peramalan yang baik. Untuk mengetahui apakah hasil peramalan metode double exponential smoothing efektif dapat dilihat dari hasil minimum error Mean Absolute Percentage Error (MAPE) pada setiap alpha (a). 
Lebih lanjut, hasil dari penelitian diharapkan dapat membantu dan mempermudah apoteker dalam melakukan pengendalian obat di apotek RS Condong Catur.

\section{Metode/Perancangan}

Pada penlitian ini metodologi yang digunakan adalah adalah waterfall (air terjun) dan dapat dilihat beberapa tahapannya pada gambar 1 .

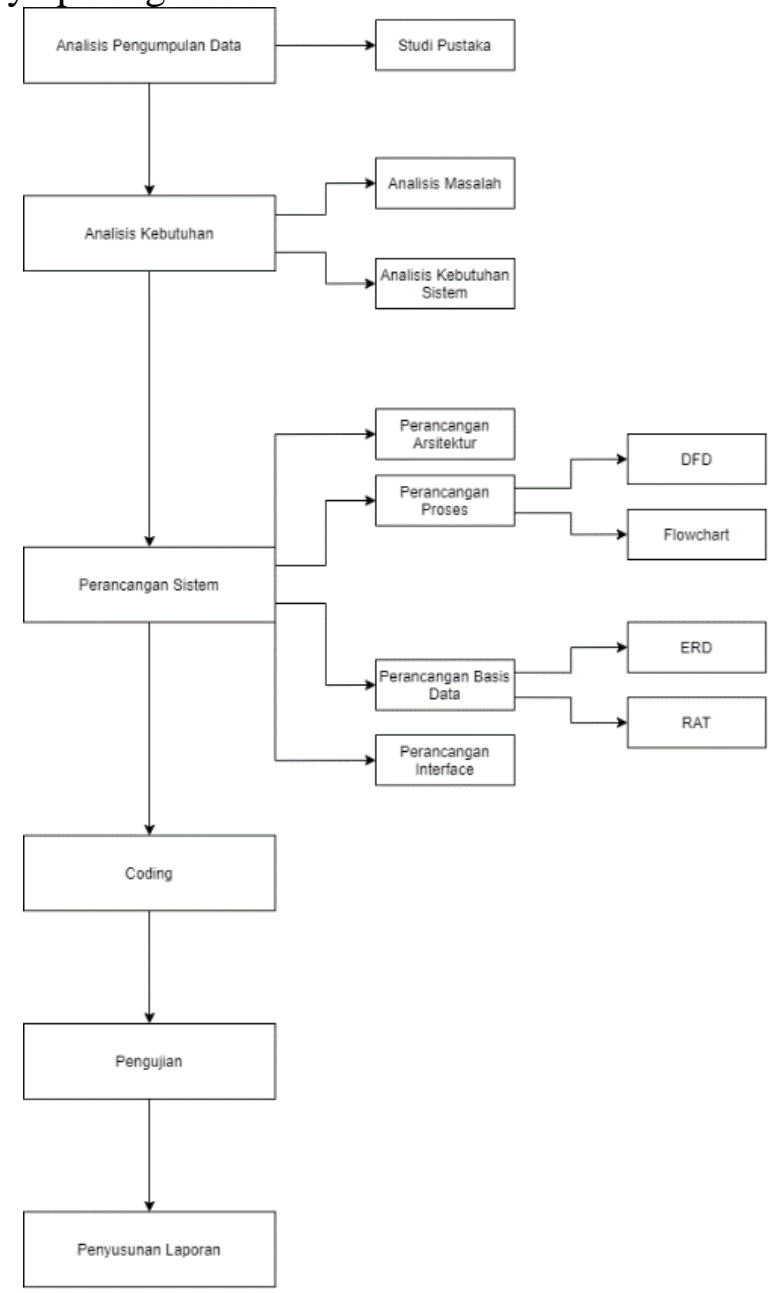

Gambar 1. Tahapan Penelitian

\subsection{Pengumpulan Data}

Pada tahap ini, data yang digunakan dalam penelitian ini merupakan data transaksi penjualan obat di apotek RS Condong Catur periode tahun 2018-2019.

\subsection{Analisis Data}

Analisis pengumpulan data bertujuan untuk mendapatkan informasi mengenai apa saja yang harus dibutuhkan untuk mendukung pembuatan sebuah sistem. Dalam hal ini analisa pengumpulan data hanya dilakukan tahap studi pustaka. Adapun yang digunakan untuk mengembangkan sistem ini adalah sebagai berikut : 
1. Data input: data transaksi penjualan obat apotek RS Condong Catur pada periode 2018-2019 yang datanya berbentuk deret waktu (time series), yang dimaksud deret waktu (time series) adalah sekumpulan data yang memiliki urutan waktu dengan rentang yang sama.

2. Data proses: input parameter alpha. Proses input parameter alpha tujuannya untuk menguji beberapa nilai parameter alpha, sehingga dapat diketahui mana alpha terbaik untuk setiap item data obat. Pada penelitian ini menggunakan alpha 0,$1 ; 0,2 ; 0,3 ; 0,4 ; 0,5 ; 0,6 ; 0,7 ; 0,8 ; 0,9$ kemudian diproses untuk mendapatkan hasil prediksi dengan menggunakan perhitungan metode peramalan double exponential smoothing.

3. Data output: Hasil pengujian terhadap data tersebut dibagi menjadi 2, yaitu 18 bulan untuk data latih dan sisa bulan lainnya digunakan untuk data uji. Hasil dari proses prediksi akan dibandingkan dengan data uji (data asli), apabila terjadi kesalahan atau nilai error yang tinggi (lebih dari 20\%) maka nilai MAPE belum dikatakan baik.

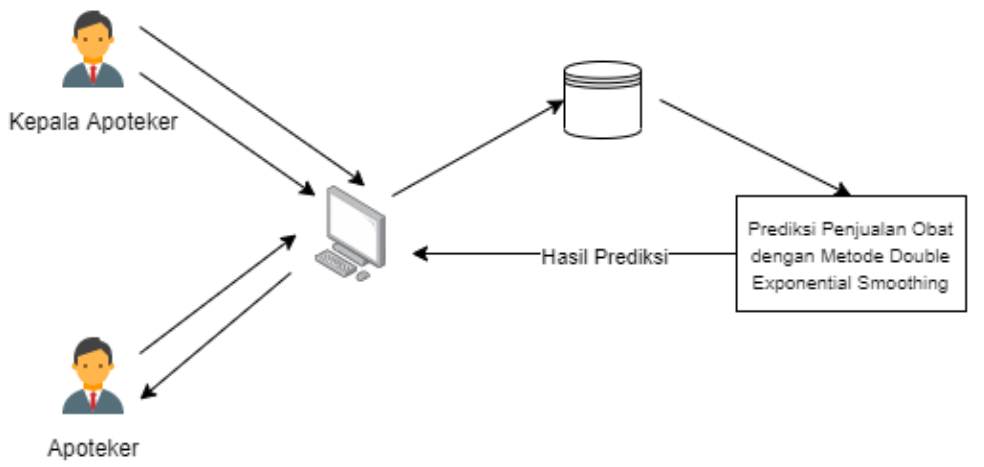

Gambar 2. Arsitektur Sistem

Pada arsitektur sistem ini dapat menampilkan hasil prediksi penjualan obat kepada admin dan kepala apoteker. Pengambilan data untuk prediksi menggunakan rekap transaksi tiap penjualan obat dari database. Selanjutnya data dikelompokkan berdasarkan bulan dan dilakukan perhitungan dengan metode double exponential smoothing. Dalam tahapan ini, setiap data obat dilakukan perhitungan sebanyak parameter alpha yang telah ditentukan. Hasil prediksi dengan nilai MAPE yang paling minimum disetiap alpha, maka alpha tersebut yang digunakan untuk prediksi penjualan obat.

\subsection{Peramalan (Forecasting)}

Peramalan (forecasting) merupakan suatu proses atau usaha untuk mengetahui peristiwaperistiwa (event) yang akan terjadi dimasa mendatang dengan berdasarkan objek, pengalamanpengalaman, ataupun data historis tertentu. Untuk memperkirakan masa depan, peramalan (forecasting) menggunakan suatu teknik analisa perhitungan dengan cara meminimumkan pengaruh kepastian terhadap pendekatan kualitatif maupun kuantitatif [2]. Peramalan dapat dijadikan dasar perencanaan suatu perusahaan baik dalam jangka pendek, menengah maupun panjang. Metode peramalan (forecasting) dapat dilakukan dengan 2 cara, yaitu metode kualitatif dan kuantitatif.

\subsection{Data Deret Waktu}

Data deret waktu (time series) adalah sekumpulan data yang memiliki urutan waktu dengan rentang yang sama (jam, hari, minggu, bulan, tahunan, dsb) dimana peramalan deret waktu meramalkan masa depan berdasarkan perilaku data masa lampau dengan memanfaatkan persamaan matematika dan statistika [10]. Contohnya seperti data daya nilai tukar uang, data 
permintaan pasokan, data ekspor gula tahunan, dsb. Secara garis besar data deret waktu dibagi menjadi yaitu stasioner dan tidak stasioner. Data stasioner adalah data deret waktu yang memiliki nilai tengah (rataan) dan ragam (fluktasi) yang kosntan dari waktu ke waktu. Metode peramalan yang termasuk dalam time series model yaitu metode penghalusan (smoothing methods), metode regresi dan metode box-jenkis [2]. Pada deret waktu (time series) terdiri dari empat pola data dalam melakukan peramalan yaitu pola data horizontal, pola data trend, pola data musiman dan pola data siklis. Pola data horizontal adalah Pola ini terjadi ketika data berfluktasi disekitar nilai rata-rata konstan. Seperti penjualannya suatu produk yaitu yang tidak naik atau turun dalam waktu tertentu. [11]. Pola data trend adalah Pola data trend terjadi ketika terdapat data dalam jangka panjang yang mengalami kenaikan atau penurunan sekuler. Seperti GNP(Gross National Produk), penjualan perusahaan, dan berbagai ekonomi atau bisnis lainnya. Pola data musiman adalah Pola data musiman terjadi ketika suatu deret data dipengaruhi oleh factor musiman (seperti hari-hari pada minggu tertentu, kuartal tahun atau bulan tertentu). Contohnya seperti penjualan es krim, data produksi tanaman, sedangakan pola data siklis yaitu Pola data yang terjadi apabila terdapat data dalam jangka panjang yang dipengaruhi oleh fluktasi ekonomi seperti yang berhubungan dengan siklus bisnis.

\subsection{Metode Penghalusan (Smoothing Method)}

Apabila data deret berkala itu bersifat statsioner maka nilai rata-rata (mean) dapat digunakan sebagai peramalan. Akan tetapi apabila data deret berkala mengandung trend ataupun pengaruh musiman maka nilai rata-rata sudah tidak mampu lagi menggambarkan pola data tersebut. Untuk menghilangkan fluktasi yang disebabkan oleh pengaruh musiman itu maka data yang tak stasioner perlu di haluskan, dengan menggunakan metode penghalusan (smoothing method). Pada model analisis deret waktu maupun model regresi, teknik peramalan dibagi lagi menjadi beberapa metode. Pada metode penghalusan (smoothing methods) terdiri dari 2 kelompok yaitu metode rata-rata (average method) dan metode penghalusan eksponensial (exponential smoothing method).

\subsection{Pemulusan eksponensial (exponential smoothing)}

Pemulusan eksponensial (exponential smoothing) adalah suatu metode yang menunjukkan pembobotan menurun secara eksponensial terhadap nilai pengamatan yang lebih lama. Oleh karena itu metode ini disebut prosedur exponential smoothing. Sama seperti moving average, metode exponential smoothing terdiri atas metode penghalusan tunggal (single exponential smoothing), ganda (double exponential smoothing), dan triple exponential smoothing. Pada metode exponential smoothing ini, revisi lanjutan dilakukan atas ramalan berdasarkan pengalaman yang lebih baru, yaitu melalui pengrataan (pemulusan). Nilai dari serentetan data yang lalu dengan cara menguranginya secara eksponensial.

\subsubsection{Double Exponential Smoothing}

Double Exponential Smoothing adalah metode yang digunakan ketika data berbentuk trend [12]. Trend adalah komponen data deret waktu yang menunjukan adanya peningkatan/penurunan dalam jangka panjang yang dihaluskan dari rata-rata pertumbuhan pada akhir masing-masing periode. Pada perhitungan metode Double Exponential Smoothing dibagi menjadi dua proses yaitu proses latih dan uji. Pada gambar 3 merupakan proses pengujian metode Double Exponential Smoothing. 


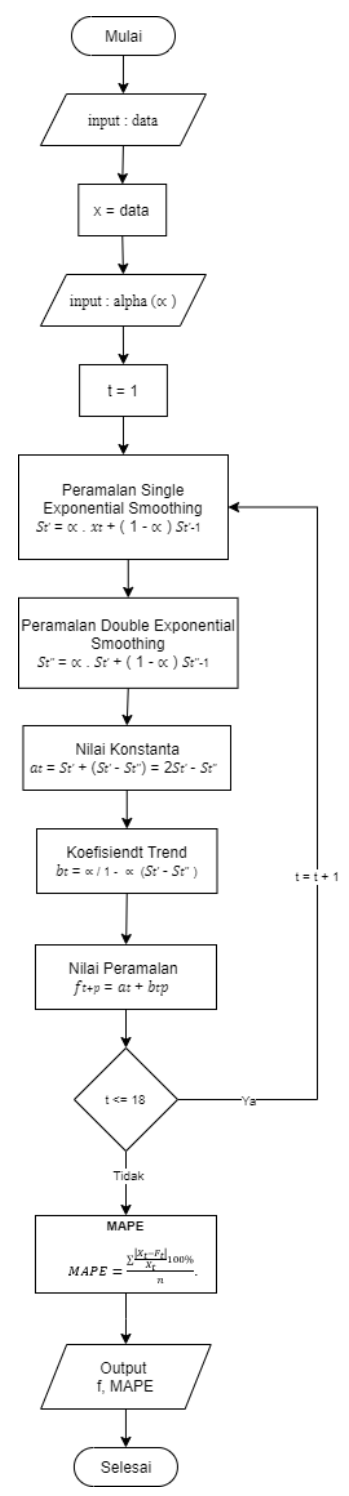

Gambar 2. Flowchart Peramalan Metode Double Exponential Smoothing

Langkah-langkah pengujian prediksi penjualan obat menggunakan Metode Double Exponential Smoothing sebagai berikut :

1. Menentukan data berdasarkan jenis kategori obat, kemudian setiap jenis data obat akan dilakukan perhitungan metode double exponential smoothing.

2. Menentukan nilai parameter alpha $(\alpha)$ yang akan digunakan dalam penghalusan (smooting). Nilai $\alpha$ bernilai 0,$1 ; 0,2 ; 0,3 ; 0,4 ; 0,5 ; 0,6 ; 0,7 ; 0,8 ; 0,9$ sehingga satu jenis obat dilakukan 9 kali perhitungan.

3. Setelah menentukan data dan nilai parameter alpha $(\alpha)$, selanjutnya dilakukan pemulusan untuk mencari nilai single exponential smoothing $\left(S^{\prime} t\right)$ dengan rumus : $S_{t}^{\prime}=\alpha \cdot X t+$ $(1-\alpha) S^{\prime} t-1$.

4. Selanjutnya yaitu menentukan nilai double exponential smoothing $\left(S^{\prime \prime}{ }_{t}\right)$ dengan rumus : $S^{\prime \prime}{ }_{t}=\alpha \cdot X t+(1-\alpha) S^{\prime} t-1$

5. Menghitung nilai $a_{t}$, dengan menggunakan rumus $a_{t}=2 S^{\prime} t-S^{\prime \prime} t$. 
6. Menghitung nilai $b_{t}$, dengan menggunakan rumus $b_{t}=\frac{a}{1-a}\left(S^{\prime} t-S^{\prime \prime} t\right)$.

7. Lalu menghitung nilai peramalan $F_{t}$ untuk periode kedepan dengan menggunakan rumus $F_{t}=a_{t}+b_{t}(m)$

8. Proses berikutnya menghitung nilai error dari hasil prediksi dengan cara menghitung nilai error MAPE dengan menggunakan rumusa $M A P E=\frac{|X t-F t| / X t}{n} x 100 \%$.

\subsubsection{Evaluasi Prediksi}

Evaluasi prediksi digunakan untuk mengetahui hasil prediksi yang akurat. Hasil prediksi yang akurat adalah prediksi yang dapat menghasilkan tingkat error (forecast error) paling minimum. Dalam menghitung forecast error terdapat empat formula yang biasanya dilakukan untuk mengevaluasi teknik peramalan, fungsinya untuk mengukur tingkat perbedaan antara hasil peramalan dan permintaan yang sebenernya terjadi [13], antara lain sebagai berikut:

\section{Rata-rata Persentase Kesalahan Absolut (Mean Absolute Precentage Error $=$ MAPE)}

MAPE merupakan ukuran kesalahan relatif. MAPE biasanya lebih berarti dibandingakan MAD karena MAPE menyatakan persentase kesalahan hasil peramalan terhadap permintaan aktual selama periode tertentu yang akan memberikan informasi persentase kesalahan terlalu tinggi atau terlalu rendah. Suatu model dikatakan sangat bagus apabila nilai MAPE berada dibawah $10 \%$ dan MAPE yang berada diantara $10 \%$ dan $20 \%$ dikatakan bagus. Secara matematis, MAPE dinyatakan sebagai berikut.

$$
\begin{aligned}
& M A P E=\frac{|X t-F t| / X t}{n} \times 100 \% \\
& X t=\text { Nilai aktual periode ke-t } \\
& F_{t}=\text { Nilai ramalan }
\end{aligned}
$$

\section{Rata-rata Deviasi Mutlak (Mean Absolute Deviation Error = MAD)}

MAD merupakan rata-rata kesalahan mutlak selama periode tertentu tanpa memperhatikan apakah hasil peramalan lebih besar atau lebih kecildibandingkan kenyatannya. Secara matematis, rumus MAD ditulis sebagai berikut:

$$
\begin{aligned}
& M A D=\sum\left|\frac{X_{t-F_{t}}}{n}\right| \\
& X t=\text { Nilai aktual periode ke- } \mathrm{t} \\
& F_{t}=\text { Nilai ramalan } \\
& n=\text { cacah data } \text { time series }
\end{aligned}
$$

\section{Rata-rata Kuadrat Kesalahan (Mean Square Error = MSE)}

MSE merupakan metode alternatif dalam suatu metode peramalan. Pendekatan ini penting karena tekhnik ini menghasilkan kesalahan yang moderat lebih di sukai oleh suatu peramalan yang menghasilkan kesalahan yang sangat besar. MSE dihitung dengan menjumlahkan kuadrat semua kesalahan peramalan pada setiap periode dan membaginya dengan jumlah periode peramalan .

$$
\begin{aligned}
& M S E=\sum e_{i}^{2}=\frac{\sum\left(X_{t}-F_{t}\right)^{2}}{n} \\
& e_{i}^{2}=\text { selisih antara hasil peramalan dengan fakta } \\
& X t=\text { Nilai aktual periode ke-t } \\
& F_{t}=\text { Nilai ramalan } \\
& n=\text { cacah data time series }
\end{aligned}
$$




\subsection{Basis Data}

Basis data adalah kumpulan data yang saling berhubungan antara satu dengan yang lain yang diorganisasikan berdasarkan struktur atau skema, tersimpan di hardware komputer dan dengan software dapat digunakan pada hal-hal tertentu. Pendefinisian basis data berupa tipe data, struktur data dan batasan-batasan data yang akan disimpan. Database merupakan komponen utama pada system informasi, karena database untuk menyimpan informasi atau data [14].

Menurut (Fathansyah, 2012) basis adalah kumpulan data yang saling berhubungan yang tersimpan dalam bentuk file/tabel/arsip secara bersama sedemikian rupa dan tanpa duplikasi data (redudansi). Untuk menggunakan database diperlukan software yaitu Database Management System (DBMS). Dengan menggunakan DBMS pengguna atau user dapat membuat, mengelola, mengontrol dan mengakses database dengan mudah, prkatis dan efisien [15]. Database terdiri dari beberapa file, record, file data, database dan character. Character adalah bagian dari data terkecil yang berupa karakter, numerik, huruf atau karakter-karakter khusus (special character) yang terbentuk suatu item data. Field merupakan suatu kumpulan atribut yang membentuk record, seperti nama, alamat dan dll. Record kumpulan dari field yang membentuk record dan menggambarkan suatu data individu tertentu., seperti data tiap karyawan. File adalah kumpulan record-record yang menggambarkan satu kesatuan data yang sejenis. Mislkan seperti mata pelajaran yang berisi semua tentang mata pelajaran. Sedangkan database merupakan kumpula dari file atau table membentuk suatu database [16].

\section{Hasil dan Pembahasan}

Pengujain dilakukan dengan memilih kategori berdasarkan satuan obat, setelah dikelompokkan berdasarkan kategori satuan obat kemudian dilakukan perhitungan menggunakan metode Double Exponential Smoothing dengan parameter alpha yang telah ditentukan yaitu 0,$1 ; 0,2$; 0,$3 ; 0,4 ; 0,5 ; 0,6 ; 0,7 ; 0,8 ; 0,9$ pada tiap obat. Pada proses perhitungan data yang digunakan merupakan data penjualan obat dari tahun 2018-2019, dimana data tersebut dikelompokkan berdasarkan bulan sehingga terdapat 24 periode. Dari 24 periode tersebut dibagi menjadi 2 dipengujian, yaitu 18 periode pertama merupakan data latih dan 6 periode berikutnya merupakan data uji. Pada sistem ini dalam melakukan proses prediksi, data dikategorikan berdasarkan satuan obat, kemudian data yang sudah dikelompokkan berdasarkan satuan obat dilakukan pengujian dengan metode double exponential smoothing. Hasil pengujian dapat dilihat pada tabel berikut untuk obat cefixime 100mg (JKN) .

Tabel 1. Hasil Pengujian Obat Cefixime 100mg (JKN)

\begin{tabular}{|c|c|r|}
\hline No & Alpha & \multicolumn{2}{|c|}{ MAPE } \\
\hline 1 & 0,1 & 9.891 \\
\hline 2 & 0,2 & 14.959 \\
\hline 3 & 0,3 & 29.438 \\
\hline 4 & 0,4 & 43.917 \\
\hline 5 & 0,5 & 56.113 \\
\hline 6 & 0,6 & 66.879 \\
\hline 7 & 0,7 & 71.305 \\
\hline 8 & 0,8 & 71.192 \\
\hline 9 & 0,9 & 65.057 \\
\hline
\end{tabular}


Setiap jenis data dilakukan 9 kali proses perhitungan dengan menggunakan berbagai alpha. Untuk mengetahui seberapa akurat hasil prediksi maka menggunakan nilai persentase error yaitu MAPE paling minimum, setelah dilakukan 9 kali proses perhitungan nilai MAPE paling minimum yang akan digunakan sebagai prediksi penjualan obat untuk periode selanjutnya. Berikut contoh hasil dari prediksi penjualan berdasarkan kategori satuan capsul.

Tabel 2. Kategori Berdasarkan Satuan Capsul

\begin{tabular}{c|l|c|r} 
No & \multicolumn{1}{|c|}{ Nama Obat } & Alpha & \multicolumn{2}{|c}{ Mape } \\
\hline 1 & Cefadroxil 500mg (Berno) & 0,4 & 14.732 \\
\hline 2 & Omeprazole cap & 0.5 & 21.335 \\
\hline 3 & CETIRIZINE 10 MG TAB & 0.2 & 15.231 \\
\hline 4 & Lansoprazole cap (JKN) & 0.3 & 15.842 \\
\hline 5 & MECOBALAMIN 500Mg & 0.5 & 11.763 \\
\hline 6 & Kapsul CaCO3 - Calcium Carbonat (HD) & 0.1 & 11.784 \\
\hline 7 & Cefixime 100mg (JKN) & 0.1 & 9.892 \\
\hline 8 & CEFIXIME 200 mg CAPSUL & 0.4 & 14.465
\end{tabular}

Nilai MAPE yang paling minimum akan ditampilkan untuk prediksi penjualan obat periode selanjutnya. Sehingga hasil pengujian pada kategori satuan obat, nilai alpha yangdigunakan pada setiap obat akan berbeda-beda. Pada kategori satuan capsul obat dihasilkan dengan ratarata alpha 0,$1 ; 0,2 ; 0,3 ; 0,4 ; 0,5$. Pada kategori satuan tablet obat dihasilkan dengan rata-rata alpha 0,$1 ; 0,2 ; 0,3 ; 0,4 ; 0,5 ; 0,7 ; 0,8 ; 0,9$. Pada kategori satuan ampul obat dihasilkan dengan rata-rata alpha 0,$1 ; 0,2 ; 0,3 ; 0,4 ; 0,5 ; 0,8$. Pada kategori satuan botol obat dihasilkan dengan rata-rata alpha 0,$1 ; 0,2 ; 0,5 ; 0,6 ; 0,7$. Pada kategori satuan tube obat dihasilkan dengan rata-rata alpha 0,1;0,3. Pada kategori satuan buah obat dihasilkan dengan alpha 0,1;0,2. Pada kategori satuan ampul obat dihasilkan dengan rata-rata alpha 0,$1 ; 0,2 ; 0,4 ; 0,8$. Pada kategori satuan piecies obat dihasilkan dengan alpha 0,$1 ; 0,2 ; 0,3 ; 0,4 ; 0,5$ dan 0,8 . Pada kategori satuan mili liter obat dihasilkan dengan rata-rata alpha 0,6 dan kategori satuan vial obat dihasilkan dengan alpha 0,7.

\section{Kesimpulan dan Saran}

Setelah dilakukan penelitian berdasarkan perancangan, pembuatan, dan pengujian program dihasilkan bahwa metode Double Exponential Smoothing dapat digunakan untuk melakukan prediksi penjualan obat di Apotek Rumah Sakit Condong Catur. Metode Double Exponential Smoothing efektif untuk data yang berpola trend seperti data penjualan obat yang berada di Apotek Rumah Sakit Condong Catur. Parameter alpha $(\alpha)$ yang digunakan pada sistem berbedabeda pada setiap jenis obat karena pola trend pada setiap penjualan obat berbeda-beda di Apotek Rumah Sakit Condong Catur. Berdasarkan hasil pengujian, nilai error Mean Absolute Percentage Error (MAPE) pada setiap obat rata-rata dibawah 20\%.

Diharapkan untuk penelitian selajutnya agar mendapatkan nilai parameter alpha ( $\alpha$ ) yang lebih baik, dapat menggunakan algoritma optimasi. Serta dapat dilakukan perbandingan dengan menggunakan algoritma forecasting yang lain sehingga dapat diketahui algoritma forecasting mana yang lebih baik pada penjualan obat di Apotek Rumah Sakit Condong Catur 


\section{Daftar Pustaka}

[1] R. P. Aji, E. S. Astuti, and H. Susilo, "INSTALASI FARMASI RUMAH SAKIT ( STUDI PADA RUMAH SAKIT UMUM Dr . SAIFUL ANWAR MALANG )," Univ. Brawijaya, pp. 1-10, 2008.

[2] H. D. E. Sinaga and N. Irawati, "Perbandingan Double Moving Average Dengan Double Exponential Smoothing Pada Peramalan," JURTEKSI (Jurnal Teknol. dan Sist. Informasi), vol. IV, no. 2, p. 8, 2018.

[3] C. V. Hudiyanti, F. A. Bachtiar, and B. D. Setiawan, "Perbandingan Double Moving Average dan Double Exponential Smoothing untuk Peramalan Jumlah Kedatangan Wisatawan Mancanegara di Bandara Ngurah Rai," J. Pengemb. Teknol. Inf. dan Ilmu Komput., vol. 3, no. 3, pp. 2667-2672, 2019.

[4] A. Purwanto and S. Hanief, "Teknik Peramalan Dengan Double Exponential Smoothing Pada Distributor Gula," J. Teknol. Inf. dan Komput., vol. 3, no. 1, pp. 362-366, 2017, doi: 10.36002/jutik.v3i1.238.

[5] R. Gustriansyah, "Analisis Metode Single Exponential Smoothing Dengan Brown Exponential Smoothing Pada Studi Kasus," pp. 7-12, 2017.

[6] R. Sari, Aplikasi Prediksi Kebutuhan Persediaan Obat pada Instalasi Farmasi Rumah Sakit DKT Jember Menggunakan Metode Double Exponential Smoothing. 2015.

[7] J. Nangi, H. Indrianti, and B. Pramono, "PERAMALAN PERSEDIAAN OBAT MENGGUNAKAN METODE TRIPLE EXPONENTIAL SMOOTHING (TES) (STUDI KASUS : INSTALASI FARMASI RSUD KAB. MUNA),” vol. 4, no. 1, p. 218, 2018.

[8] H. Tanuwijaya, "Penerapan Metode Winter ' S Exponential Smoothing Dan Single Moving Average Dalam Sistem Informasi," Semin. Nas. Manaj. Teknol. XI, pp. 1-10, 2010.

[9] G. L. S. Satibi, Achmad Fudholi, Eirene Copalcanty Tuko, "Pengendalian Persediaan , Fasilitas Penyimpanan dan Distribusi pada Industri Farmasi dalam Mendukung Ketersediaan Obat Era JKN," J. Manaj. dan Pelayanan Farm., vol. 9, no. 1, pp. 27-37, 2019.

[10] L. Octavia, Tanti and Yulia, Yulia dan Lydia, "Peramalan stok barang untuk membantu pengambilan keputusan pembelian barang pada toko bangunan xyz dengan metode arima," Semin. Nas. Inform., vol. 1, no. semnasIF, pp. 2-7, 2015.

[11] P. Silvianti and A. Rizki, "Metode Peramalan Deret Waktu," pp. 1-10, 2015.

[12] J. Bidangan, I. Purnamasari, and M. N. Hayati, "Perbandingan Peramalan Metode Double Exponential Smoothing Satu Parameter Brown Dan Metode Double Exponential Smoothing Dua Parameter Holt," Stat. FMIPA Univ. Mulawarman, vol. 4, no. 1, p. 15, 2016, [Online]. Available: https://jurnal.unimus.ac.id/index.php/statistik/article/view/2003.

[13] N. L. A. K. Yuniastari and I. W. W. Wirawan, "Peramalan Permintaan Produk Perak Menggunakan Metode Simple Moving Average Dan Single Exponential Smoothing," Sist. dan Inform. STIKOM Bali, vol. 9, no. 1, pp. 97-106, 2016.

[14] N. D. Nathasia and a. E. Wicaksono, "Penerapan Teknik Kriptografi Stream-Cipher Untuk Pengaman Basis Data," ICT Research Center UNAS, vol. 6, no. 1. pp. 1-22, 2011.

[15] H. A. Puspitosari, Pemrograman Web Database dengan PHP dan MySQL. Yogyakarta: Skripta, 2010. 
[16] F. Irmansyah, "Pengantar Database," Pengantar Database, pp. 1-13, 2003, [Online]. Available: https://staff.blog.ui.ac.id/r-suti/files/2010/03/pengantardb.pdf. 